\title{
EGGCASE CONSTRUCTION AND FURTHER OBSERVATIONS ON THE SEXUAL BEHAVIOR OF THE SPIDER SICARIUS (ARANEAE: SICARIIDAE)**
}

\author{
By Herbert W. Levi and Lorna R. Levi \\ Museum of Comparative Zoology, Harvard University
}

The eggcase of Sicarius is unique among spiders. Its masonry wall resembles in texture the nests of mud dauber wasps. And, unlike other spider eggcases, it is buried in sand, attached to stones. We do not know of any other masonry construction by spiders, or of other buried eggsacs. Some spiders incorporate sand grains and detritus into their webs or their trapdoors. The European theridiid Achaearanea saxatile (C. L. Koch) makes a thimble-shaped retreat for herself and her silken eggsac (Pötzsch, 1963), and covers the thimble with large sand grains and little stones. The colonial European zodariids, Zodarion germanicum (C. L. Koch) and Z. elegans Simon, build retreats under stones. Each semispherical retreat is covered by sand grains from the surroundings, and pieces of bark and spruce needles are woven into the wall. The retreat is used by the spider and the eggsac is hung up in it. As far as I know, the building of the retreat has not been observed. Wiehle (1953) illustrates a row of large setae in front of the zodariid spinnerets and peculiar branched setae that cover the legs and tarsi. These setae are perhaps used for handling the detritus.

The unusual Sicarius eggcase was first noted by Simon ( I 899) ${ }^{1}$. Although we have two species of Sicarius in culture the possibility of watching eggsac construction seemed at first remote because the only eggcase made in the laboratory appeared to have been constructed while the spider was covered by sand.

Sicarius belongs to a small family of little-studied spiders, distributed in the southern hemisphere and related to the more widespread Loxoscelidae and Scytodidae. Any behavior observations are of phylogenetic interest. The several species of Sicarius inhabit deserts and bury themselves in the sand (Reiskind, 1966.) The burying, the material of the eggcase and the burying of the eggcase are probably adaptations to avoid extreme heat. The spiders presumably evolved

\footnotetext{
*The research was supported in part by Public Health Service Research Grant AI-01944 from the National Institute of Allergy and Infectious Diseases. Manuscript received by the editor October 4, 1968.

${ }^{1}$ Birabén (1939) reported and described the egg cases for Argentinian species.
} 

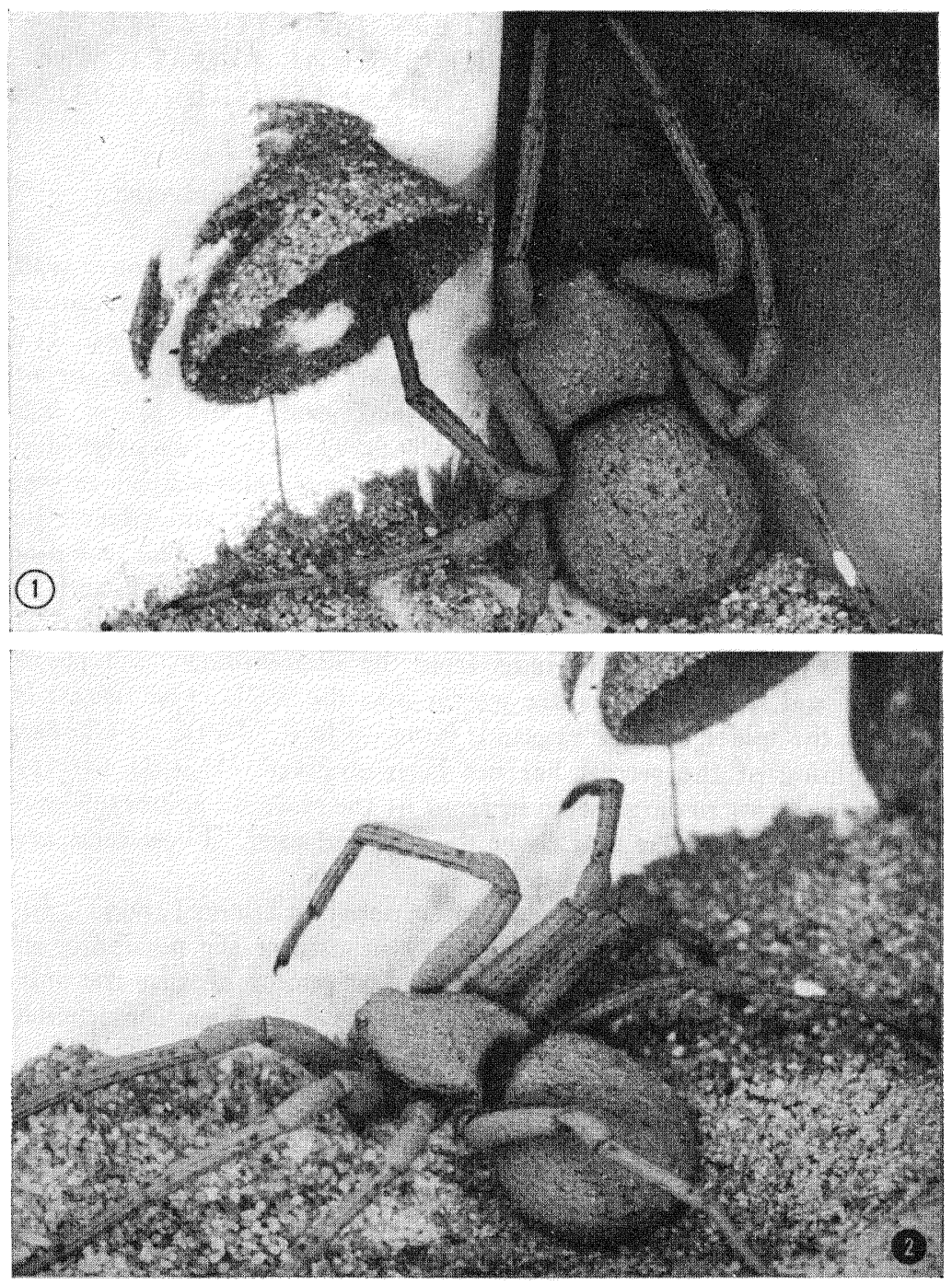

Fig. 1. Sicarius "sp. 1" female with the foundation of the eggcase. The basal disc still has a bare spot, while the upper rim has been built up. On the left side are some foundation attachments not used. The sand next to the spider on the ground has been scraped away to the bottom of the container, while in later photographs sand has been thrown back into this area by the spider. The total length of the spider is $18 \mathrm{~mm}$. The photograph was taken on 13 June.

Fig. 2. Female Sicarius rocking her abdomen in the sand. The abdomen is held at an unusual angle to the prosoma while picking up fine sand particles. The photograph was taken later on 13 June. 
in desert areas and from there a few species have invaded neighboring savannah land. The sparing use of silk (Fig. Io) may also be an adaptation to the periodically sparse food supply and protein intake of desert inhabitants.

Here two observations are reported. During the first the spider was left undisturbed; during the second, to facilitate photography and observation, the spider's work was interrupted.

The spider under observation belongs to Sicarius sp. "no. I," originating in Tucumán Province, Argentina. The female is the same individual reported on in the previous paper (Levi, r968.)

On 5 April I968, at 8 A.M. a basal masonry disc was found on the paper lining of a vertical side of the plastic polystyrene container. One edge was $5 \mathrm{~mm}$ high, the opposite rim missing. From time to time the female scratched in the sand on the bottom of the container, throwing sand grains underneath her abdomen and sometimes rocking her abdomen from side to side. At IO A.M. the spider was clinging to the upper rim of the disc tapping the lower rim with the tip of her abdomen, but it could not be seen whether spinnerets were involved or the anal tubercle. The mouth was definitely not used. At 8 P.M. ( $20 \mathrm{~h}$ ) the disc was complete but the lower rim still lacking. On 6 April in the morning, no change was noticed; the spider had not worked during the night. On 7 April, in the morning, the upper wall was higher, about I mm high, and strongly concave. The lower rim was only slightly raised above the basal disc. The spider was buried. At 5 P.M. ( $\mathrm{I} 7 \mathrm{~h}$ ) the spider was seen clinging to the cup, not moving; at 8 P.M. $(20 \mathrm{~h})$ the female had moved slightly and a yellowish clump of eggs was seen inside the cup. The female now attached silk threads criss-cross over the top of the cup. She touched her spinnerets to the rim of the cup then drew a thread to the center and returned to the rim. Light seemed to disturb her and she stopped working. At 4:30 A.M. on 9 April, the lid was plastered over and the spider was slowly digging in the sand. At 7 A.M. the female was still digging, but in a different place; after digging a few strokes she stopped for a long time. At 8:30 A.M. the female was found buried, but not in the place where she had been digging.

Although it could not be seen exactly how the sand was incorporated into the wall of the cup, the mouthparts were not used. It is of interest that the eggcase was started on 5 April and finished on 9 April, over a time span of four days, the female interrupting her work at intervals to return later. The construction of the eggsac of most spiders observed is started and completed within several hours. The 
eggcase was not constructed within the sand, but the base of the lower rim was about $5 \mathrm{~mm}$ above the level of the substrate. The eggcase was made 9 months after first mating in July, I967. This period is generally much shorter in other spiders: days, or at most weeks.

On 4 June I968, a smudge mark was again observed on the vertical paper wall. On 5 June, in the morning a foundation was present (Fig. I). The spider container was moved and placed in light on a work desk for easier observation. Perhaps as a result of this disturbance the spider did not resume work until the night of 12-13 June. The cup was slowly built up and its walls, as well as the mud lining, seemed complete on the morning of 14 June. Interrupting her building on 13 June, the spider was observed to mate again. (Since construction of the first eggsac the spider had crossed the cardboard partition into the compartment of the male.) It was seen that the masonry construction material is made by incorporating sand with silk. The spider, jumping down from the eggcase, throws sand back with the first two legs as if beginning to bury herself (Reiskind, I966.) However, instead of jumping into the depression, the spider bends her abdomen down so far that the pedicel shows, and pushes her abdomen into the pile of sand thrown up, rocking slowly from side to side (Fig. 2). The spider then moves up to the rim with a disc shaped load of sand around the spinnerets (Fig. 3) and pulls threads out of the spinnerets with the usual abdominal motions up and down (away from the rim and approaching it) and at times sideways, incorporating sand grains. From the motion it was assumed that silk is used to incorporate the sand into the wall.

The timing in one rapid sequence was as follows: at Io A.M., spider jumps down on the sand; I5 sec later, she throws sand with her front legs; 5 sec she rocks abdomen in sand for Io sec; all motion stops for $55 \mathrm{sec}$; spider jumps with load of sand up to the rim of the eggcase, and after sitting quietly, continues construction on the rim. I min $35 \mathrm{sec}$ after jumping up, she jumps down again, turns, throws sand, rocks her abdomen, rests, and jumps up to the rim. She first touches the rim with palps. Temporarily in throwing back sand, the spider removed all sand to the bare plastic bottom under the eggcase, but later she replaced the sand. The male once emerged from the sand, put his long legs over the female, then backed up and away.

On I 4 June, 9 P.M. (2I h) the rim seemed finished and perfectly circular (Fig. 4.) The next observation was made at 3 A.M., I 5 June. The eggs must have been laid, as the eggcase was finished covered by the lid (Fig. 5). At 6 A.M. the female walked around in the sand, 

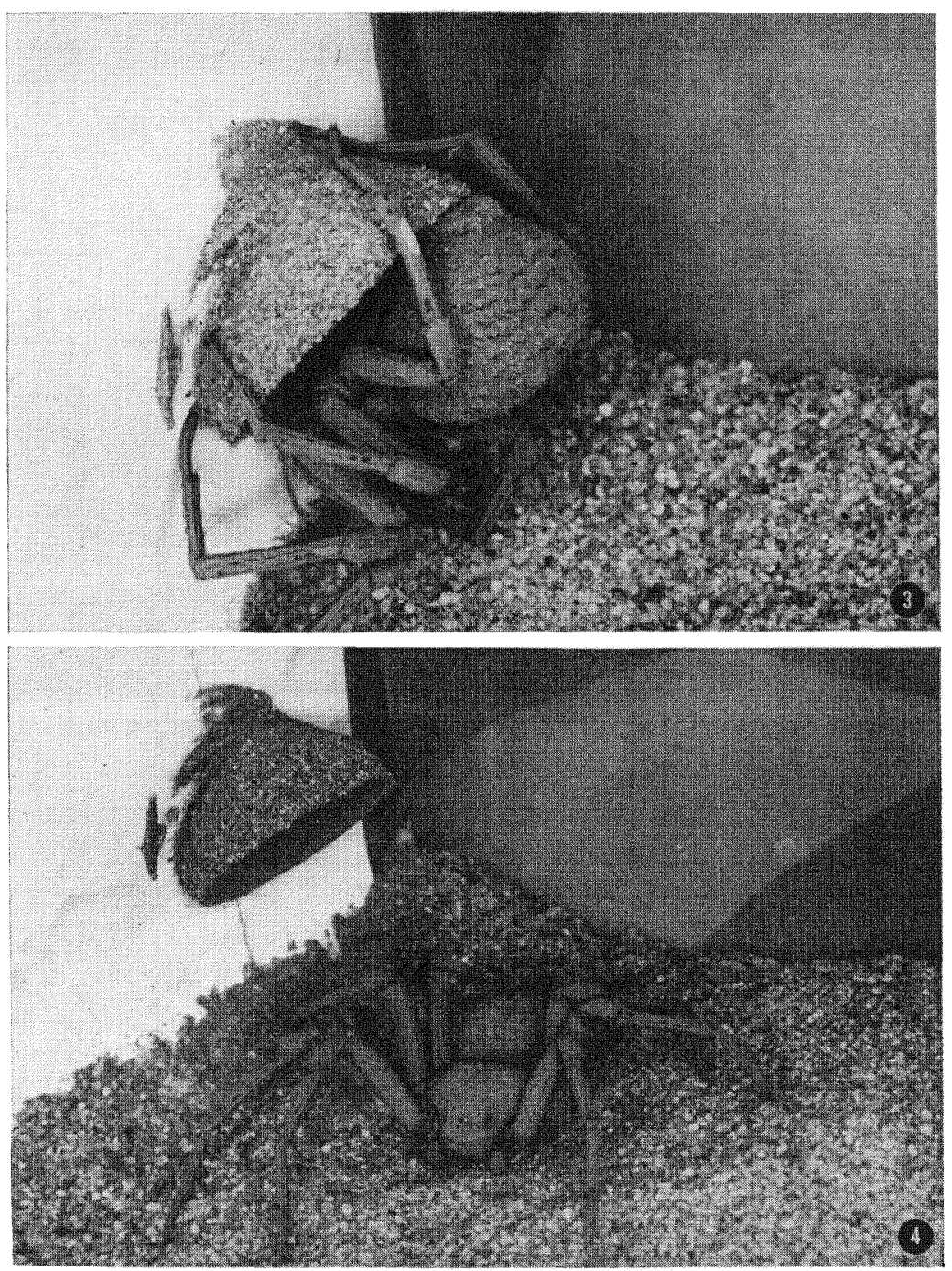

Fig. 3. Female Sicarius incorporating fine sand particles, held in a disc around spinnerets, into the eggcase wall with silk. Notice the difference in grain size of the substrate and the material picked up. Photograph taken minutes after Fig. 2.

Fig. 4. Eggcase ready to receive the eggs. The rim is now circular and smooth. Photograph taken 14 June at $21 \mathrm{~h}$. 

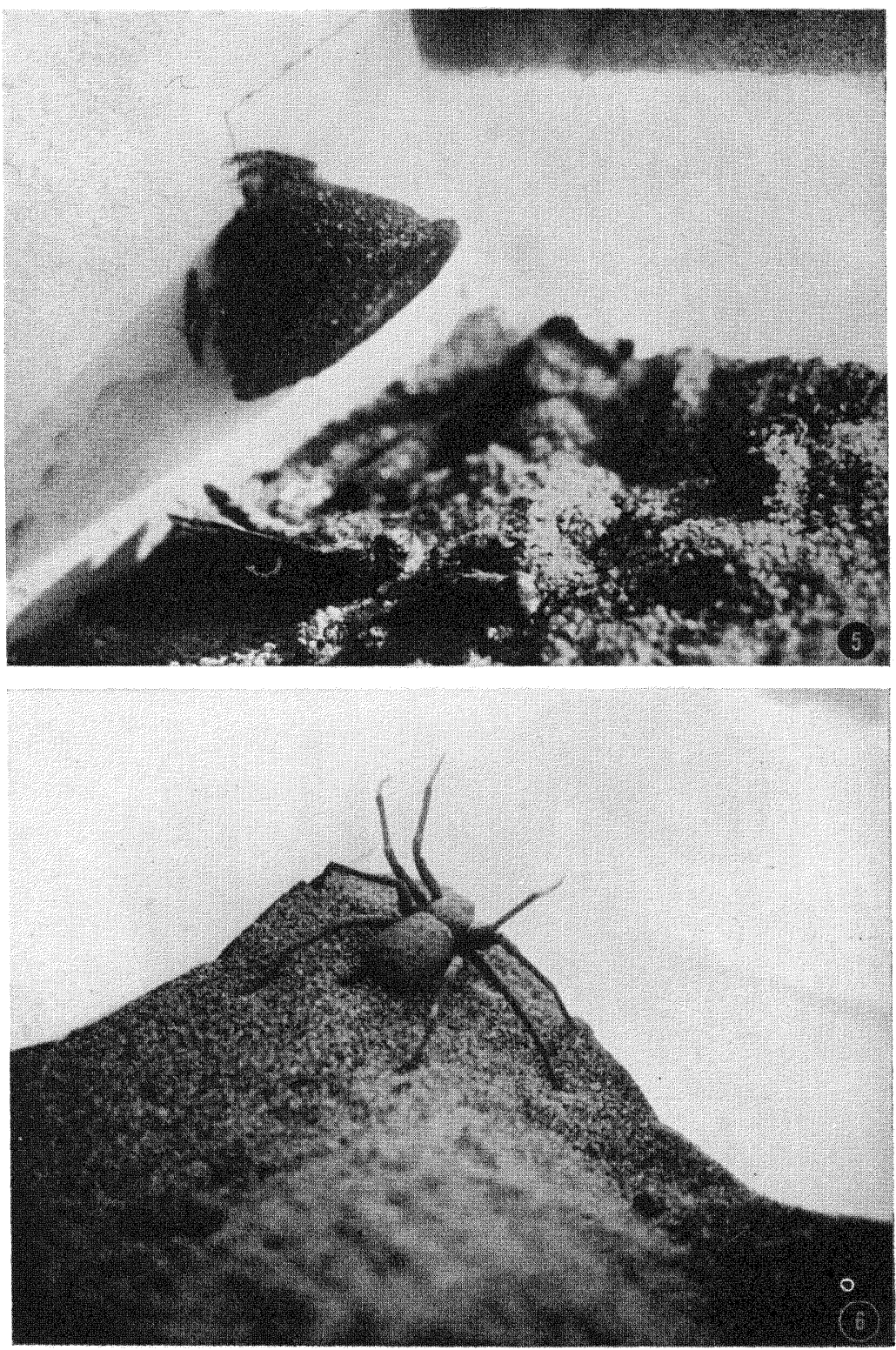

Fig. 5. The finished eggcase. The edge of the cap overhangs the walls. Photograph taken before the eggcase was buried, 15 June.

Fig. 6. The eggcase has disappeared under the sand thrown over it. The line between 2 nd and $3 \mathrm{rd} \mathrm{left}$ legs of the spider is the same as the one in Fig. 5 above and to the right of the eggcase. 
digging, but did not fit herself into the hole. This observation corresponded with that of the first eggcase construction. But now with strong movements of the first and second legs, the spider began throwing sand $10 \mathrm{~cm}$ back, toward the eggcase. The sand noisily struck against the paper lined plastic wall of the container. It was first thought that this action was to fill the hole in the sand under the eggcase, the hole produced by throwing sand back for the eggcase construction. But the spider continued changing her position around the eggcase, always remaining about $10 \mathrm{~cm}$ away, throwing sand toward the eggcase. The accuracy was not great and often the sand was thrown at an angle $45^{\circ}$ off. But the spider must have been able to determine the direction of the eggcase from her changing position. The throwing back of sand reminded one of a dog digging a hole. The motions were those illustrated by Reiskind ( I 966, Fig. I). By I I :30 A.M. the eggcase was buried under several $\mathrm{cm}$ of sand (Fig. 6) and the female dug herself into the sand and disappeared.

From the start to completion it took the spider I I days - perhaps prolonged because of the disturbance. However, the spider continued construction and did not start out anew as might have been expected. Four days after completing the work the female was found dead on the sand surface. The cause of death is unknown. It may have been dehydration resulting from frequent disturbance.

Preserved Sicarius were examined under the microscope. Unlike juveniles and males, adult females have their spinnerets almost hidden by a crown of long setae many layers thick. Only the posterior spinnerets show (Figs. 7, 8). (Sicarius lacks the large colulus characteristic of the related Loxosceles.) Under the microscope the setae were found to be feathered (Fig. 9) and about I mm long. A needle run through these setae became dusty. To test the assumption that these setae can pick up sand mechanically, one female preserved in alcohol was dried and the spider's abdomen was rocked in the sand. No sand grains were picked up at all - only dust, the particles about I/ IO the diameter of sand particles. And, indeed, the particles in the wall of the eggcase were all much smaller than the majority of the sand grains in the spider's container. The setae around the spinnerets sift out the right size particles from the sand thrown back by the female. The sand grains were later measured and found to be $0.2-0.4 \mathrm{~mm}$ in diameter. Some of the fine particles that washed off the female, preserved in alcohol after she died, measured $0.02-0.06$ $\mathrm{mm}$ diameter. Some of these particles may have come from setae on other parts of the female's body to which dust clings readily, giving the animal the color of the background. The difference in grain size 


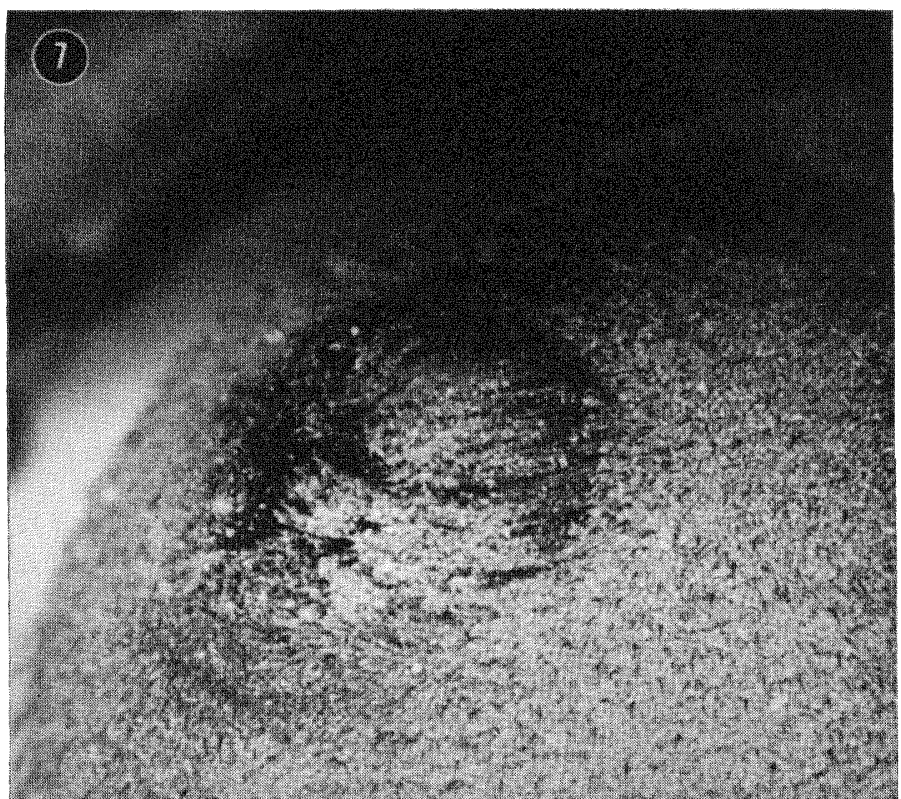

Fig. 7. Setae surrounding spinnerets that hold sand, seen from the side. At upper right is the genital groove.

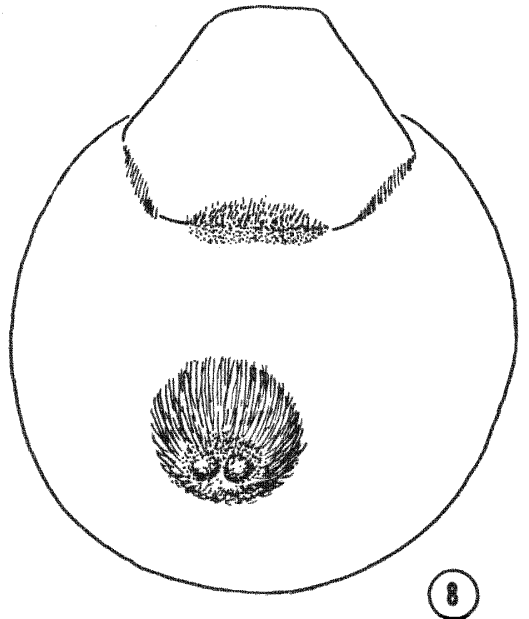

Fig. 8. Diagram of venter of female Loxosceles abdomen showing the long setae around and almost completely covering the spinnerets. The genital groove also has dense hair. 
of the particles in the eggcase and the sand can be seen in Figs. 3 and 4.

The first eggcase had a hole near the top rim on the morning of 16 August, 1968, more than four months after its construction (Fig. I I ). The intervening summer had been unusually hot with many days over $30^{\circ} \mathrm{C}$. There were 2 young on the sand and during the course of the day one after another climbed sideways out of the hole, jumped to the sand (Fig. I2-I4) and shortly after, buried themselves using the same motions as the adults (Reiskind, 1966). In an attempt to photograph the slow exodus of the young, the eggcase was carefully broken off, and placed on the sand. The egg case broke off cleanly, but since it did not have a back, some young spilled out and others left rapidly, one after another, through the tiny hole. Several that left in a hurry still had their molted skins clinging to the abdomen
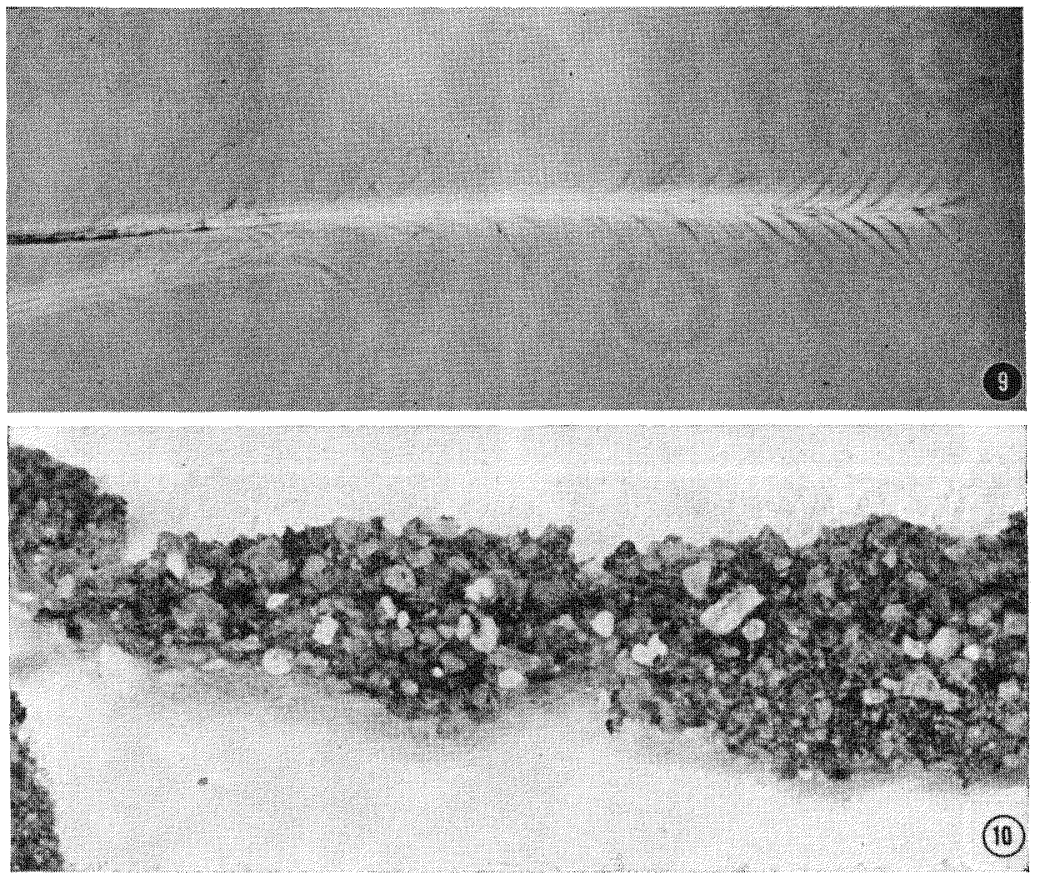

Fig. 9. A seta removed showing the branches to which dust particles cling. The seta is about $1 \mathrm{~mm}$ long; the section shown is about $0.5 \mathrm{~mm}$ long, photographed with phase microscopy.

Fig. 10. A portion of the basal disc of the eggcase. Only very few threads are used to hold the sand together. 

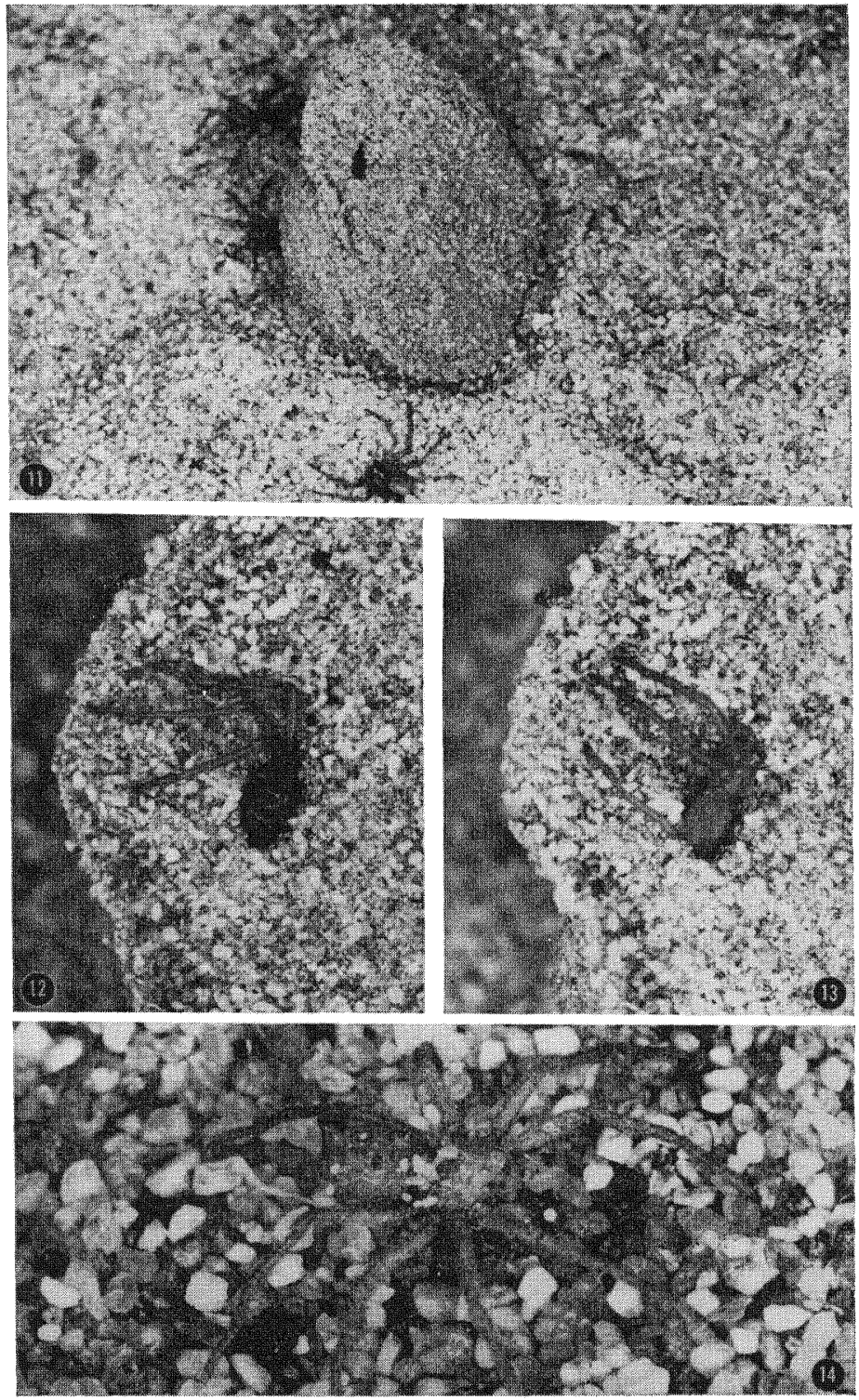

Fig. 11. The eggcase after the young have started to emerge. To facilitate photographing, the eggcase was removed from its attachment to the wall and placed on sand. The hole is near the upper edge. Several young, each about $2.5 \mathrm{~mm}$ long, are seen on the sand.

Fig. 12. One after another the young spiderlings emerge from the hole. The legs appear first.

Fig. 13. The body moves sideways through the hole.

Fig. 14. The young already have some sand grains clinging to their bodies. This individual left the eggcase when it was taken off the wall, and still has an exuvium attached to the abdomen. 


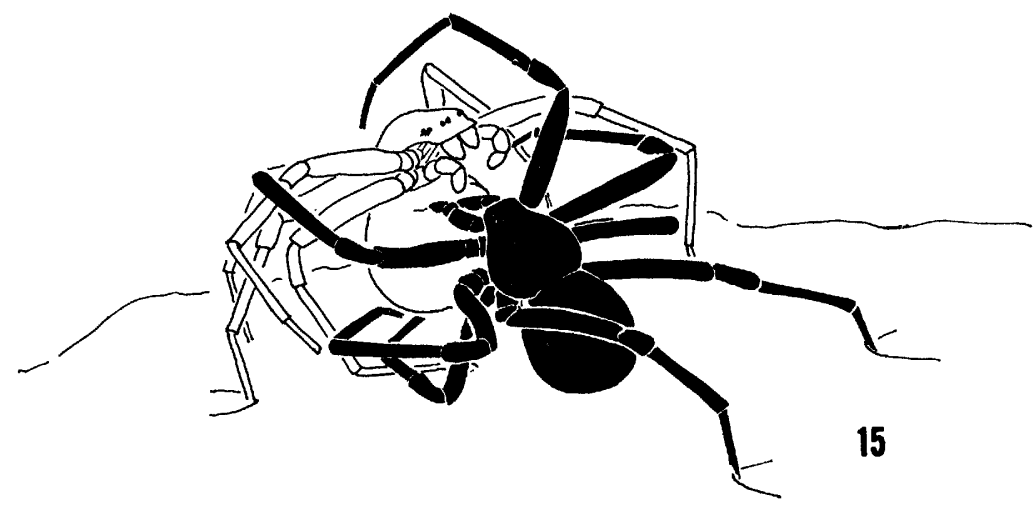

Fig. 15. Sicarius sp. mating on 13 June. The male has been illustrated black, the female white. The drawing was made from a photograph.

(Fig. 14). Some that had left the eggcase in the morning were feeding on drosophila flies by early afternoon. The young, about 2.5 $\mathrm{mm}$ long, at first looked skinny, but soon filled out. By the following day no more young were seen to emerge. The plastic cage was jarred to make the spiderlings emerge from the sand, and about forty spiderlings were counted. The eggcase was examined. In it were ro shrivelled eggs that had not hatched and numerous exuviae. Many exuviae had an egg membrane attached. Apparently the young left the eggs, molted, and then made the hole and emerged. The eggcase had no silk lining but under the lid a few silk threads crossed. Apparently, after the cup was finished (Fig. 4) and filled with eggs, the eggs were secured by a few silk strands before the lid was constructed. The silk strands might also support the masonry lid. The contents of the second eggcase proved to be infertile and did not hatch.

During construction of the eggcase, on June 13 at about 4 P.M. $(\mathrm{I} 6 \mathrm{~h})$ the female was observed mating. The constancy of mating position within spider families was discussed in a previous paper and the pair observed mating was the same one photographed mating previously (fig. I, Levi, I968). During the first matings observed, the female had been turned over with her abdomen in horizontal position, in the mating observed now, perhaps because of obstructions, the abdomen was vertical, the cephalothorax of the female still bent, but now horizontal over the male and the male was at an angle near vertical to the female (Fig. 15). The differences in positions of different matings of the same pair were as great as those puzzling differences observed by Dabelow (1958) in individuals of Scytodes thoracica coming from different parts of Europe. 
BirabÉN, M.

\section{References Cited}

1939. Sobre nidos de arañas del género Thomisoides. Notas Mus. La Plata 4: 361-365.

DABELOW, $S$.

1958. Zur Biologie der Leimschleuderspinne Scytodes thoracica (Latreille.) Zool. Jahrb. Abt. System. 86: 85-162.

LEVI, H. W.

1968. Predatory and sexual behavior of the spider Sicarius (Araneae: Sicariidae) Psyche 74: 320-330 (1967).

Pötzsch, J.

1963. Von der Brutfürsorge heimischer Spinnen. Die Neue Brehm Bücherei, Ziemsen Verl. Wittenberg Lutherstadt.

REISKind, J.

1966. Self burying behavior in the genus Sicarius (Araneae, Sicariidae)

Psyche 72: 218-224 (1965).

Simon, E.

1899. Note sur le cocon ovigère d'un Sicarius du Pérou. Bull. Soc. Entomol. France 1899: 267-368.

Wiehle, H.

1953. Orthognatha, Cribellatae, Haplogynae, Entelegynae (Pholcidae, Zodariidae, Oxyopidae, Mimetidae, Nesticidae) in F. Dahl, Die Tierwelt Deutschlands 42(9): 1-150. 

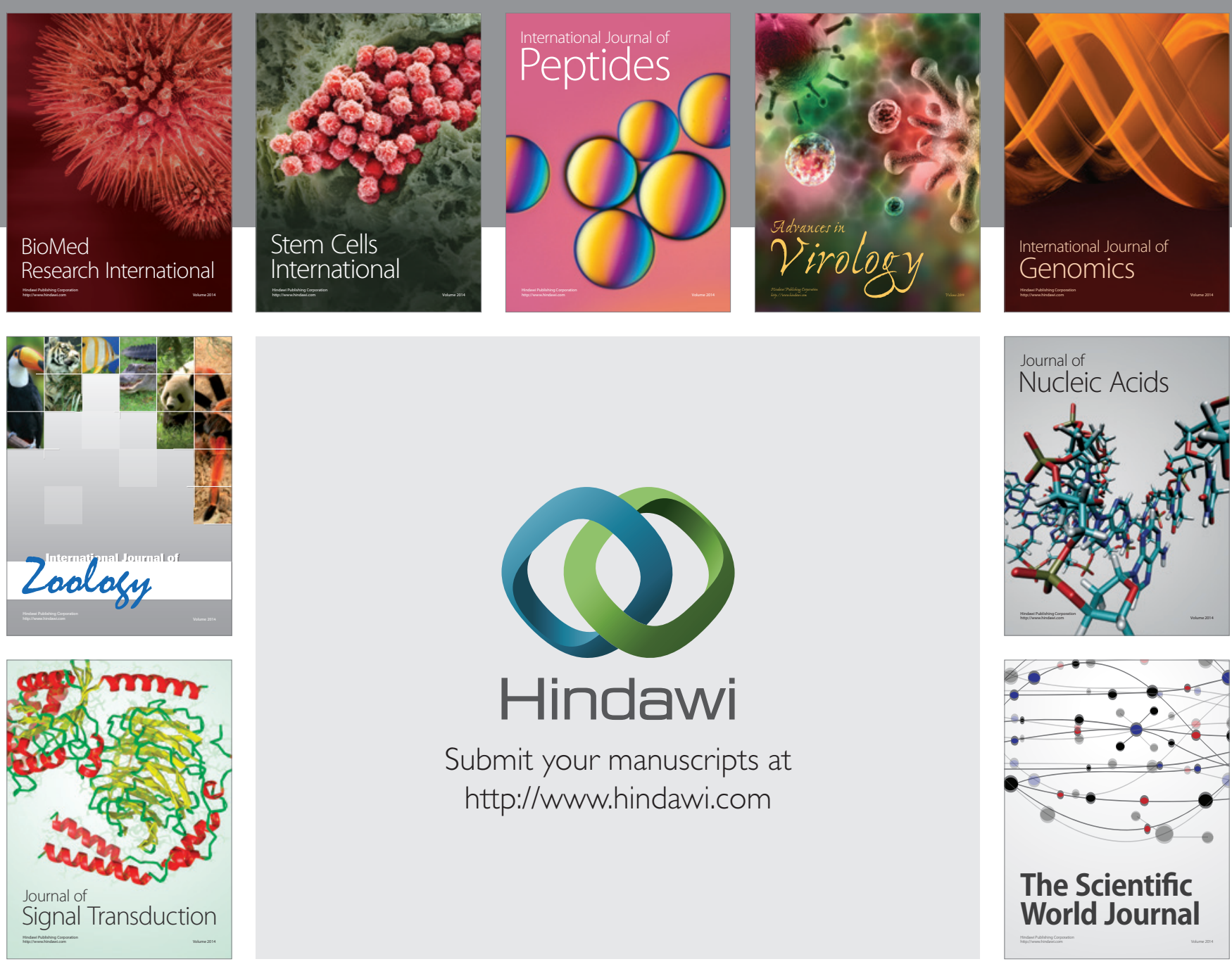

Submit your manuscripts at

http://www.hindawi.com
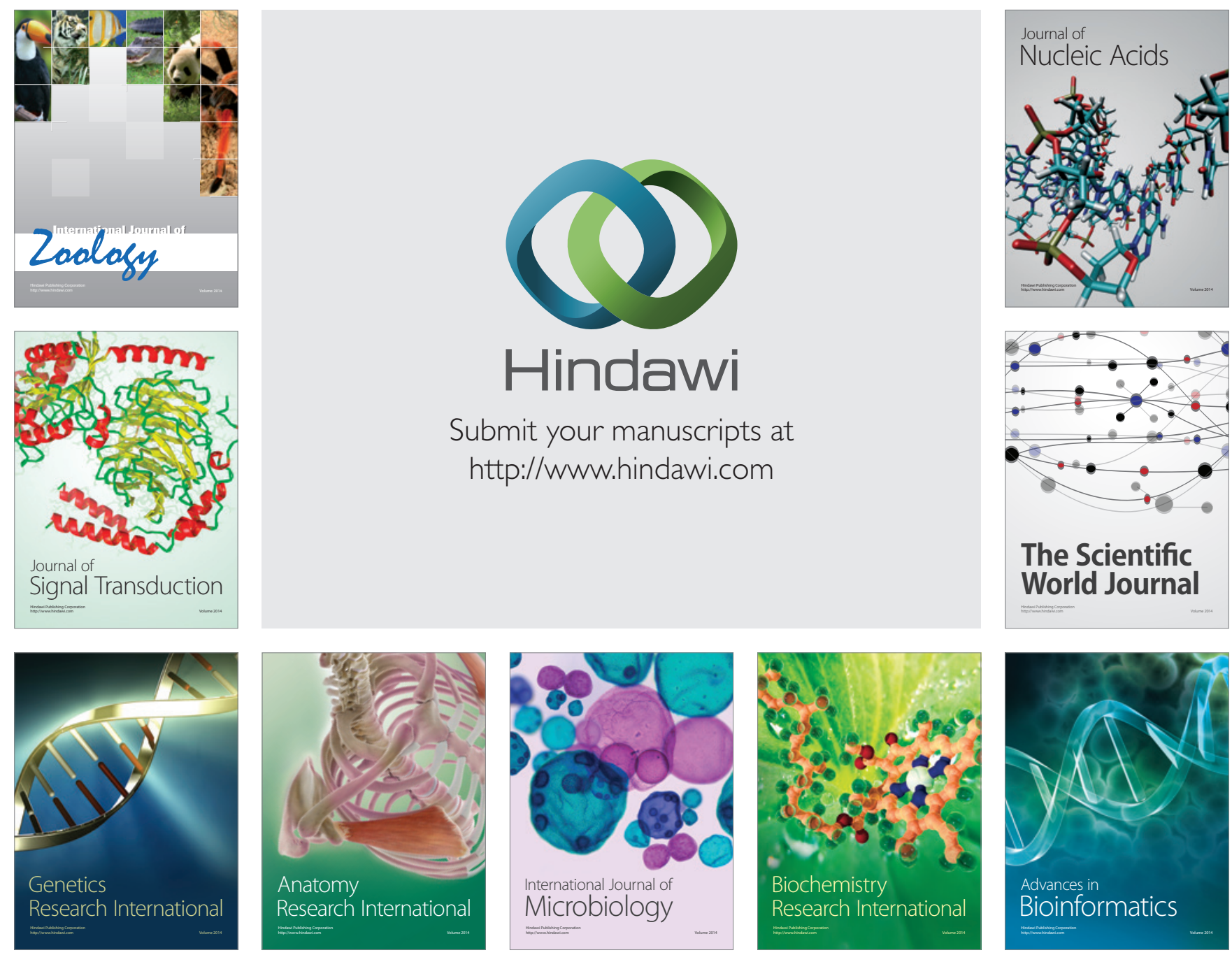

The Scientific World Journal
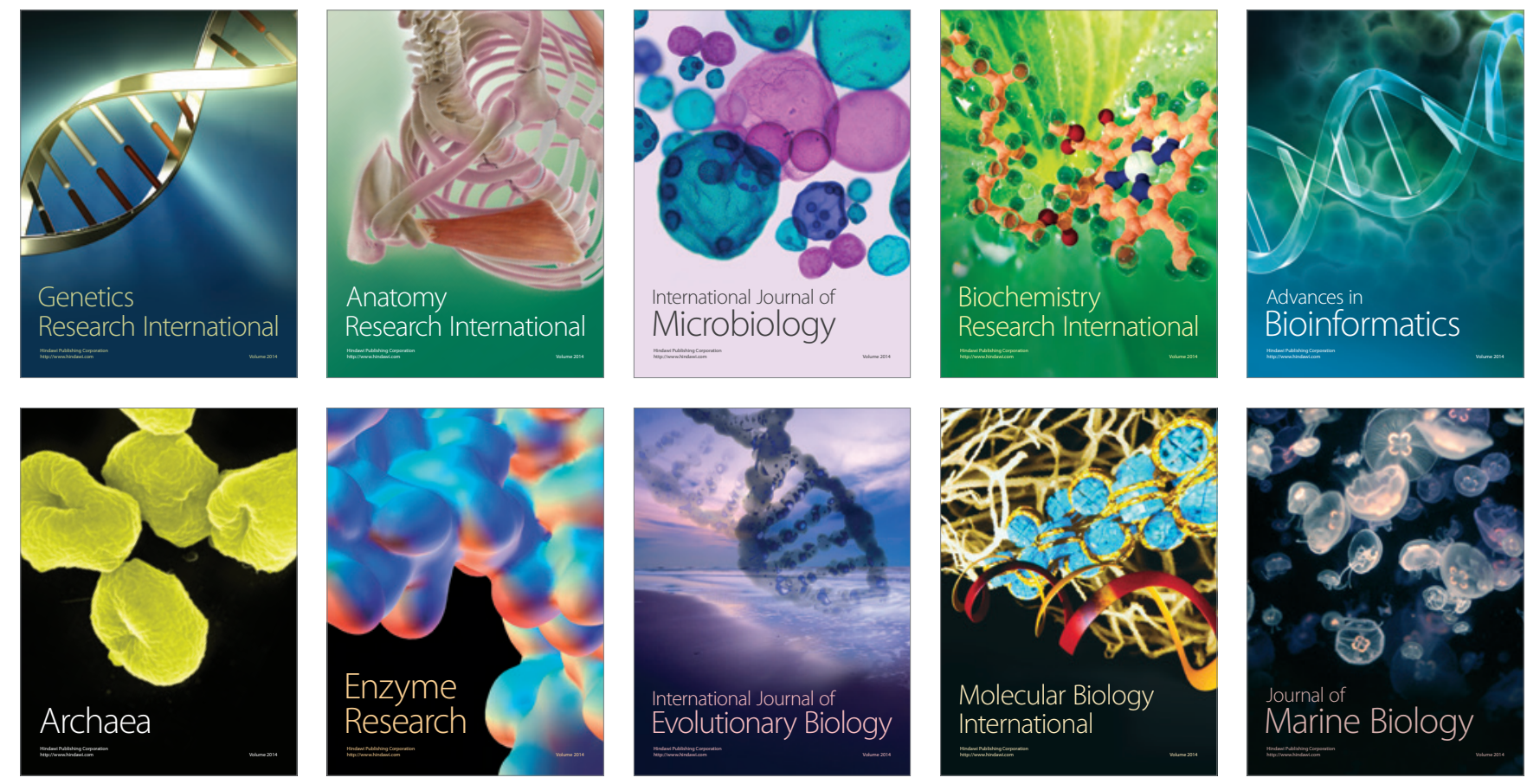